\title{
Framing and policy change after shooting rampages: a comparative analysis of discourse networks
}

\author{
Steffen Hurka and Kerstin Nebel
}

\begin{abstract}
In this contribution, we comparatively analyse the discourse net works generated by three shooting rampages. We formulate hypotheses on the extent to which (a) the framing cohesion of the status quo coalition and (b) the per ceived causal complexity of the event are associated with varying degrees of sub sequent gun policy change. Drawing on news reports in major newspapers, we collect information on actors and frames and systematically analyse those data with the tool Discourse Network Analyzer. The networks show that major gun policy change is possible if the status quo coalition is internally divided and the event's causal complexity is low. Incremental adjustments are also likely if the status quo coalition lacks cohesion, but if additionally causal complexity is high, i.e., the problem signified by the event is disputed. Finally, if the status quo coalition manages to retain its framing cohesion, deadlock is likely to occur regardless of the event's perceived causal complexity.
\end{abstract}

KEY WORDS Discourse network analysis; framing; gun policy; morality policy; policy change.

\section{INTRODUCTION}

As typical 'un-ness' events (Hewitt 1983: 10), shooting rampages are unexpected, unscheduled and unpleasant. They quickly attract popular attention and instantly wipe any other issue from the political agenda. From a political science perspective, however, the question of how such shootings exert their impact on public policies has remained largely unaddressed. The few existing studies mainly focused on the most widely perceived shooting to date in Littleton (Colorado) in 1999, placing strong emphasis on the importance of media framing for the evolution of the public discourse and the political process (Birkland and Lawrence 2009; Haider-Markel and Joslyn 2001). Despite this overwhelming United States (US) focus of the relevant literature, shooting rampages occur across the globe at more or less regular intervals. In 2011, the devastating shooting on the Norwegian island Utøya reminded the world that the abuse of firearms is not a purely American phenomenon.

In the context of this collection, our contribution highlights the relevance of external shocks as a very specific aspect of morality policy-making and thereby 
complements other contributions which put their focus on the comparative analysis of long-term change processes (Euchner et al. 2013). While we focus on shooting rampages as one example of an external shock with particular significance for gun policy, other areas of morality policy are also susceptible to sudden events that have the potential to focus and accelerate public discourse (Heichel et al. 2013). The reactions that follow such types of events have been characterized as 'moral panics' (Cohen 2002), suggesting that the resulting discourse is often based on a perceived threat to core societal values.

We suggest in line with Knill (2013) that the regulation of firearms can best be described as a latent morality policy. Even though contestation around the issue is not purely value-based, values often become salient as a corollary of an external shock. In gun policy, similar to other areas of morality policy, this value conflict relates to a dimension between the poles of individual freedom and collective security. Can a society tolerate the possession of guns by individual citizens and, if so, to what extent should it be controlled? How many rights should the government enjoy vis-à-vis its citizens? How large is the residual risk a society can accept? All of these questions can hardly be answered in functionalist terms, as they require a judgment that boils down to basic values.

In this contribution, we examine the role discursive elements play in the process of crisis-induced policy change. We suggest that, in the aftermath of shooting rampages, framing assumes a central role for the setting of the political agenda and the possibility of subsequent changes in the affected country's firearm regime. Based on Kingdon's (2003) arguments on the agenda-setting potential of focusing events and inspired by recent contributions by Boin et al. (2009) on framing contests, we suggest that two discourse properties are particularly relevant: (a) the framing cohesion of the status quo coalition; and (b) the overall diversity of interpretative frames advanced in response to the events as an indicator of discursive complexity. We test our expectations against empirical evidence from three events: the shootings at Dunblane (United Kingdom, 1996); Erfurt (Germany, 2002); and Zug (Switzerland, 2001). While the shooting at Dunblane resulted in a prohibition of private handgun ownership in Great Britain, the Erfurt shooting led to a range of incremental adjustments in Germany's gun policies and the Zug shooting did not cause any change in the Swiss firearm regime. The respective data are the issue frames endorsed and refuted by the involved actors in two major, quality newspapers within the first month after the respective incident. We categorize and analyse those frames both descriptively and using a new network analytic tool called Discourse Network Analyzer (DNA) (Leifeld 2012).

The contribution is structured as follows: We first address the theoretical foundations of our study and present the three research hypotheses. Secondly, we describe and justify our case selection and provide information about our data and method. We then present the empirical evidence, both descriptively and analytically. The article concludes with a brief summary, some theoretical implications and guidance for future research. 


\section{EXTERNAL SHOCKS, FRAMING AND POLICY CHANGE}

There is little scholarly dispute over the relevance of external shocks for the explanation of policy change and all major theoretical frameworks incorporate the concept, albeit with varying terminology and different connotations (Baumgartner and Jones 1993; Kingdon 2003; Sabatier 1998). In one way or the other, all of those frameworks acknowledge that policy change becomes more likely if certain events highlight (or are perceived to highlight) the need for reform. Yet, the frameworks differ with regard to their proposed causal mechanisms which link the external shock to policy change. We lack the space to review those theoretical arguments in detail, but argue that one of the most appealing has been advanced by Kingdon (2003) in his multiple streams approach. Following Kingdon's line of reasoning, the chance for policy change increases when a policy window opens and if this policy window is perceived by one or several policy entrepreneurs as an opportunity to push their cause. As a result, a previously neglected or even ignored issue can suddenly gain traction and access the public agenda. As Kingdon (2003: 98) notes, focusing events 'reinforce some preexisting perception of a problem, focus attention on a problem that was already "in the back of people's minds". Yet, focusing events are often highly complex and as such invite competing causal attributions. One and the same event can be interpreted through several lenses and thereby lead to interpretative conflict over the event's main underlying cause, and accordingly, over the lessons that should be drawn from it.

This latter argument has its roots in social constructivist approaches, which have taught us that social conditions are not automatically treated as social problems (Rochefort and Cobb 1993). In order to elevate an existing condition to a problem, a significant number of actors must perceive the condition as severe enough to demand political action. Corresponding shifts in problem perceptions become particularly likely when new information becomes available. Sometimes, this information comes in the form of focusing events (Birkland 2006; Kingdon 2003), which are 'sudden, relatively rare, can be reasonably defined as harmful [... and are] known to policymakers and the public virtually simultaneously' (Birkland 2006: 2). Such events lead to extreme increases of media attention and thereby often provide political decisionmakers with the urge 'to do something' in order to fight a social problem which had largely gone unnoticed by the general population. Focusing events like shooting rampages can thereby serve as catalysts for policy change by highlighting previously neglected areas of public policy. Therefore, if we want to understand why and to what extent policies change after an external shock, we first need to understand how the external shock comes to be framed as an indicator of a social problem, and even more importantly which social problem. In other words, in order to gain a better understanding of the impact of external shocks, we need to pay close attention to the way the shock is perceived and its causes are portrayed (Boin et al. 2009; HaiderMarkel and Joslyn 2001; Stone 1989). 
A focusing event rarely ever passes without attempts to exploit the crisis (Boin et al. 2009). Despite initial claims from all sides that the event is incomprehensible and inexplicable, it rarely takes long until attempts at comprehension and explanation contribute to an opening of the corresponding policy window. As Birkland and Lawrence (2009) have demonstrated, shooting rampages are prime examples of such events that can be subjected to competing interpretative frames. But how do such framing contests unfold and what can we learn from them with regard to policy change?

In their model of the policy game, Boin et al. (2009) suggest that the framing strategies chosen by advocates of the status quo and advocates of change determine the occurrence and degree of policy change after an external shock. We endorse this argument, but go one step further and relax the assumption that the two coalitions are by definition unitary entities, both of which can only follow one of two strategies (Boin et al. 2009: 90). Instead, we argue in line with Schmitt et al. (2013) that what matters for the occurrence of policy change is the cohesiveness of the coalitions in terms of the frames endorsed and refuted by their members in the wake of a focusing event like a shooting rampage. Since shooting rampages are generally cohesively interpreted by gun policy change advocates as events that legitimize their policy goals, we suggest that the critical question is how the framing of the status quo coalition unfolds. If the advocates of the status quo continue to unequivocally resist gun-related policy change, we expect deadlock to occur because the original distribution of power essentially remains unchanged. If, however, a significant amount of actors from the status quo coalition defects as a result of the event, policy change will occur, because the status quo coalition will struggle to sustain its resistance in the face of declining cohesion. ${ }^{1}$

Yet, under the condition that the status quo coalition disintegrates, what determines the extent of policy change we should expect? We suggest that the degree of gun policy change after a shooting rampage should be strongly related to the event's perceived causal complexity. The more different causes can be brought to bear in order to explain the event, the harder it will get for the change advocates in the gun policy subsystem to convince the status quo coalition that the event has implications for gun policy arrangements. This is because more complex events enable the gun status quo advocates to divert attention to other policy areas in order to contain or prevent change on the gun issue. On the other hand, the more the debate is focused on one particular issue, e.g., guns, the more difficult it will get for an already fractionalized status quo coalition to prevent major policy change. We decided to pay particular attention to the gun issue, because it is the only issue that is invariably present after shooting rampages, compared to other issues which only occasionally become salient and are more context-specific. Despite this focus on one particular policy area, we think that our general arguments about coalition cohesion and discursive complexity can and should be transferred and tested with other types of external shocks and other areas of public policy. 
Table 1 Hypotheses

\begin{tabular}{lll}
\hline & \multicolumn{2}{c}{ Cohesion of SQ advocates } \\
\cline { 2 - 3 } Perceived causal complexity & \multicolumn{1}{c}{ Low } & High \\
\hline Low & H1: Major change & H3: Deadlock \\
High & H2: Incremental change & H3: Deadlock \\
\hline
\end{tabular}

Based on our theoretical considerations, we expect the following relationships to hold after shooting rampages:

$\mathrm{H} 1$ : If the status quo advocates are not cohesive and the perceived causal complexity is low (i.e., the discourse is focused on guns), major gun policy change becomes more likely.

$\mathrm{H} 2$ : If the status quo advocates are not cohesive and the perceived causal complexity is high (i.e., the discourse is dispersed), incremental gun policy change becomes more likely.

H3: If the status quo advocates are cohesive, gun policy deadlock becomes more likely, regardless of perceived causal complexity.

Table 1 summarizes those expectations.

\section{CASE SELECTION AND DESCRIPTION}

So far, existing empirical research on the nexus between external shocks and policy change has mainly focused on technological failures like nuclear or natural disasters (e.g., Albright 2011; Birkland 2006; Nohrstedt 2008). Some studies also analysed regulatory responses to specific types of events like dog attacks (Lodge and Hood 2002), food scandals (Lodge 2011) or explosions in firework factories (de Vries 2004). Contributing to this line of inquiry, we selected three shooting rampages for comparative purposes based on their varying impacts on the gun policies of the countries in which they occurred:

Dunblane: On 13 March 1996, Thomas Hamilton (aged 43) entered a primary school in the Scottish town of Dunblane, shooting 16 children and one teacher before committing suicide. The perpetrator had been a member of the local gun club and therefore had had easy access to the weapon he used for the massacre. As a result of the shooting and the subsequent inquiry led by Lord Cullen, the Conservative government under John Major banned all private handguns with calibres above .22. After the elections in 1997, the new Labour government under Tony Blair extended the ban to all handguns.

Erfurt: Robert Steinhäuser (aged 19), a former student of the GutenbergGymnasium in Erfurt, Germany, entered the school on 26 April 2002, shooting 13 faculty members, two students, one police officer and himself. Like 
Thomas Hamilton, Steinhäuser had been a member of a gun club and used his sporting arms for the massacre. Ironically, the German Bundestag had tightened the national gun legislation on the same day the shooting took place. In the following debate, those changes were immediately questioned for their allegedly too limited magnitude and a consensus quickly emerged that some rules needed to be tightened even further. This led to a range of incremental adjustments including tighter age requirements, the prohibition of pumpguns with pistol grips and the introduction of compulsory medicalpsychological tests for marksmen under the age of 25.

Zug: The third event occurred in the cantonal parliament of the Swiss town Zug on 27 September 2001. Friedrich Leibacher (aged 57) entered the plenary and shot 14 politicians before committing suicide. The perpetrator had had a long and ongoing dispute with the local administration. After several controversies which he had unsuccessfully taken to court, he was of the opinion that a conspiracy existed in Zug's administration and government. Leibacher had stored the weapons legally at home. However, the shooting did not lead to any changes in the Swiss firearm regime.

The most obvious difference between the three events is the venue in which they took place. One could argue that the simple fact that the Dunblane and Erfurt incidents were school shootings makes policy change more likely because of the particular gruesomeness associated with such shootings. However, this would not explain why other school shootings, like the one in Littleton (United States of America, 1999) did not lead to policy change (Birkland and Lawrence 2009) and why other, school-unrelated shootings, like the one in Port Arthur (Australia, 1996) did (Chapman et al. 2006). Therefore, we argue that the three cases are appropriate for our purpose, especially given the fact that all three were carried out with legal weapons and resulted in a comparable number of casualties.

\section{METHOD AND DATA}

DNA is a new tool in social network analysis, developed in order to enable researchers to identify discourse coalitions in a policy field via qualitative category-based content analysis (Leifeld 2012). The approach has two central features that make it the preferred option for our analysis. First, DNA allows us to identify actors and their most preferred frames and then convert these structured data into discourse networks. ${ }^{2}$ This approach has both theoretical and methodological advantages vis-à-vis other approaches (see Leifeld [2012] for a more detailed discussion). Second, DNA is the first elaborate tool that allows for the quantitative analysis of discourse data and thereby opens venues for a structured comparative approach - a goal which had been elusive in discourse analysis for a long time. Thus, the innovation of DNA primarily lies in its potential to analyse actors and ideas simultaneously and thereby identify and compare discourse coalitions empirically instead of merely assuming 
their existence. This creates the possibility of pinpointing the extent of contestation around a given policy issue and visualizing the cohesion as well as the defection rates of different discourse coalitions.

Our analysis draws on data collected from newspapers in the three countries in which the massacres took place. We chose two quality daily newspapers for each country and collected all articles published within the first month after the incident that dealt with the respective event. ${ }^{3}$ We chose this time period for two reasons. First, we are primarily interested in initial frames, that is, the direct reactions to the event. Second, we noticed that the decay of media attention followed similar patterns in all three cases (see Figure 1). After an initial spike in media attention, the number of articles devoted to the events declined and converged to zero within the first month.

After having collected the respective articles, we scanned them manually for event-related statements. ${ }^{4}$ We ignored both comments from individual reporters and statements made in letters to the editor. We excluded the former owing to the possibility of bias arising through our newspaper selection and the latter primarily because of their arguably rather minor impact. Thus, our analytical focus lies primarily on representatives of political parties and interest groups, although we also collected statements from researchers and civil servants.

Four different features are coded for every statement: actor; organization; category; and agreement. If, for example, The Independent writes that 'The Labour leader said the review should consider tightening the law on hand guns in private possession' (Brown 1996), we code this as: Tony Blair (actor); Labour (organization); Guns (category); agreement (yes). With regard to gun policy,

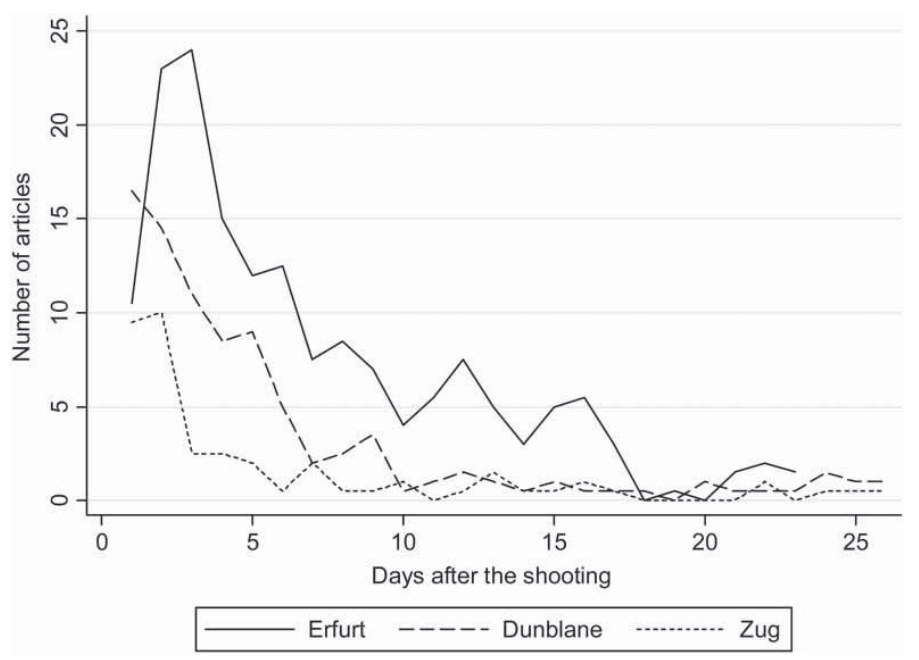

Figure 1 Decay of media attention after the shootings Note: Average values for the two newspapers per country. National holidays and Sundays omitted. 
we distinguished between statements demanding stricter measures (e.g., stricter age requirements, prohibition of certain weapons, etc.) and statements in favour of the status quo (e.g., opposition to 'knee-jerk' reactions). The same applies to demands for security measures (e.g., video surveillance, metal detectors, etc.) and corresponding rejection of such measures (e.g., public buildings should not become fortresses). The media category distinguishes statements which call for prohibitions and/or censorship in the media sector (violent films, video games, etc.) and statements which refuse such reactions. The society category incorporates statements that highlight societal neglect as a cause for the shooting and demand diffuse consequences like increased social cohesion and awareness. The politics category summarizes all positive and negative statements on general procedural consequences of the shooting, like calls for political inquiries. In the education category pros and cons about changes in the educational system of the country are summarized. The criminal justice category incorporates statements about increasing control and punishment of paedophiliacs (Dunblane specific). And finally, the lifting legal age category deals with claims about changing the legal age from 18 to 21 years (Erfurt specific).

We did not define the above mentioned categories a priori, but developed them in a check-and-revise style during the coding process. This is a common approach in discourse network analysis, since it is hardly possible to establish an exhaustive set of categories in a deductive way prior to the empirical research. It is very likely that sets of statements which had originally not been anticipated are found during the coding process (Leifeld 2012: 52). Thus, given the fact that we only had a preliminary idea about the emerging diversity of frames, this inductive proceeding proved to be the only alternative. The three cases were coded separately by the authors and the coding was continuously updated in the face of inconsistencies and contradictions. Although this procedure does not allow us to compute classical reliability scores, we are confident that our coding is consistent and complete.

We are aware of the potential validity problems caused by relying entirely on newspaper data. However, news media are the only source of information that provides us with a reasonably broad and comparable overview of the involved actors and their preferred issue frames. Other arenas of public debate like parliamentary hearings or plenary debates only give voice to a pre-selected pool of actors, sometimes focus exclusively on previously defined policy issues and, even more importantly, are handled very differently in different political systems.

\section{DESCRIPTIVE STATISTICS - ACTORS AND FRAMES}

The three events generated very different levels of discourse participation. While we counted 108 different actors after the Erfurt shooting, we only counted 48 in Dunblane and 40 in Zug. Several reasons could be responsible for this difference. As Jemphrey and Berrington (2000: 477) observed, the 'coverage of Dunblane was exceptional in terms of the level of restraint and sensitivity shown towards the bereaved, the survivors and the community', which was paralleled by an 
initial reluctance from many actors to politicize the event. Additionally, the lower number of political parties in Great Britain naturally focuses attention on a few key actors. With regard to Zug, it must be noted that the shooting took place only two weeks after the 9/11 attacks, which certainly had effects on the political agenda and, accordingly, the attention devoted to the Zug shooting. Nevertheless, all three events sparked a sharp increase in public attention. In all three cases, politicians were the origin of roughly two-thirds of all statements. In Erfurt and Dunblane, interest group representatives also participated in the political discourse to a relevant extent. The remaining statements came from diverse sources like administration officials, religious leaders or police representatives.

With regard to content, the dominant focus of the debate was quite different in the aftermath of the three shootings (see Figure 2). While the observers of the Dunblane shooting predominantly cited arguments referring to gun policy arrangements during the first month after the incident, the Zug debate exhibited a clear focus on matters of public security. The main focus in Erfurt was on the gun issue, but the debate was quite dispersed and also related to the question of whether the legal age should be lifted in general and issues of education. The focus on security matters in the aftermath of the Zug shooting deflected attention from the gun issue, and many of the gun-related statements made after the Zug shooting argued that the event did not highlight gun availability as a social problem - a feature that strongly distinguishes the Zug case from the other two cases.

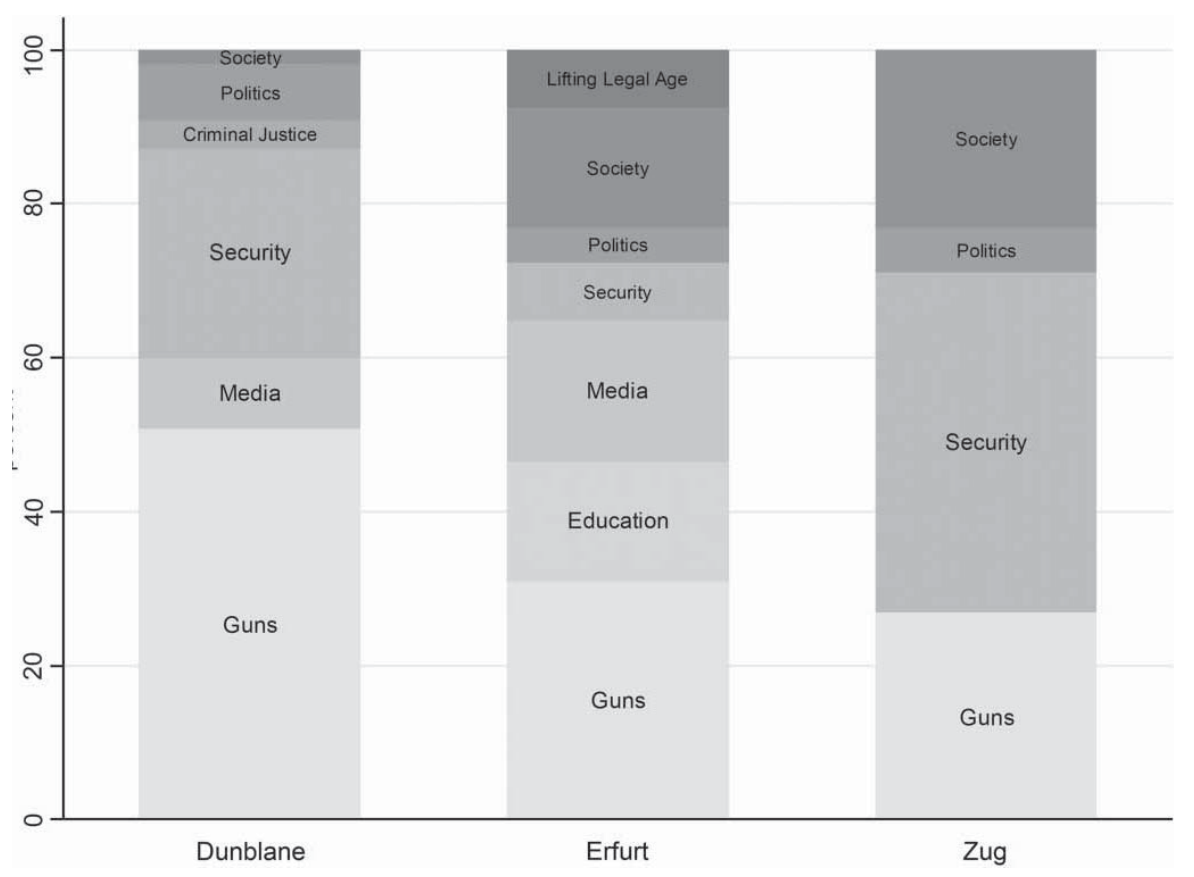

Figure 2 Statements per frame (percentages) 


\section{DISCOURSE NETWORK ANALYSIS - TRACING THE PATTERNS OF FRAMING CONTESTS}

There are several ways to visualize discourse networks (Leifeld 2012). However, taking into account the problem that the depiction of discourse networks requires a lot of space, we must focus on one network type in this contribution. We decided to provide affiliation networks, because they allow us to compare the discursive relevance of different policy issues at the same time. Figures 3-5 display the results. The size of the rectangular frame nodes corresponds to the relative frequency of the respective frame. Solid lines indicate an actor's demand for change, dashed lines indicate that the actor refutes the need for change and dotted lines indicate that the actor made contradictory statements.

\section{Dunblane - discursive foundations of major policy change}

As the Dunblane affiliation network (Figure 3) shows, the discourse clearly focused on the gun issue, while other issues were only discussed to a much lesser extent.

Within the gun discourse, the most visible actors were politicians from the three major political parties in Great Britain: Conservatives; Labour politicians; and Liberal Democrats. The Labour party and the Liberal Democrats formed a cohesive coalition that demanded changes in gun policies, whereas the Conservative party was split between advocates of change and advocates
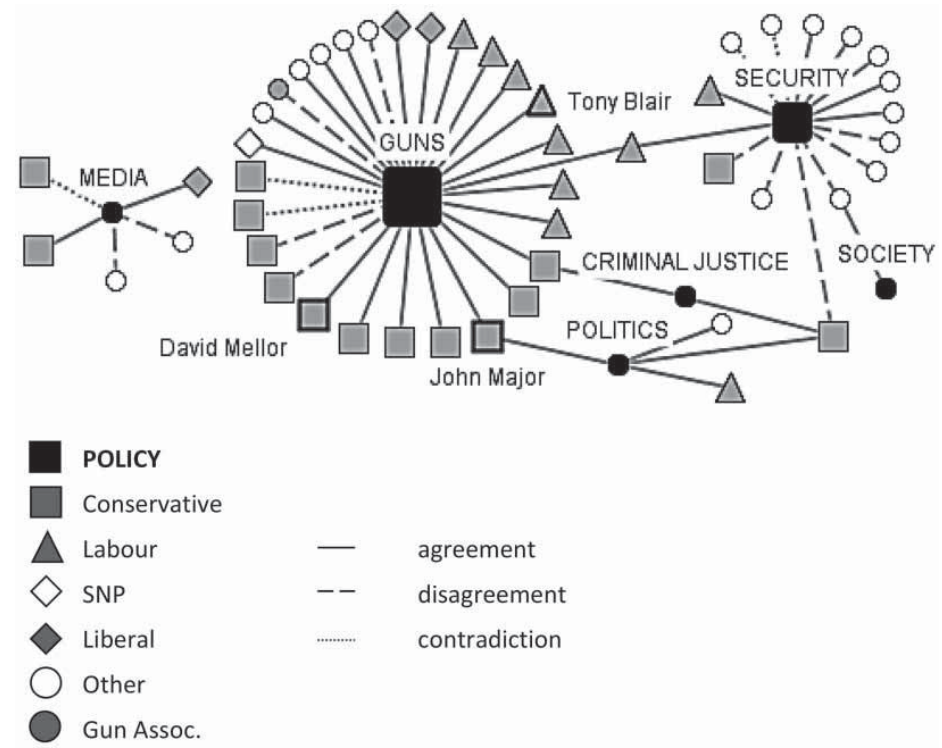

Figure 3 Dunblane discourse network 
of the status quo. However, the majority of Conservative politicians in the discourse made positive statements on possible gun policy changes and, most importantly, Prime Minister John Major did not openly resist change and soon endorsed Labour's demands for a review of British firearm policies. In addition, the most visible Conservative actor in the immediate aftermath of the shooting, Member of Parliament (MP) David Mellor, advocated a total ban of private handguns early on. The Labour party, led by opposition leader Tony Blair, demonstrated exceptional cohesion in its demand for tighter gun controls.

Of course, the displayed network is only a snapshot of the immediate political reactions to the tragedy and many subsequent events contributed to the decision to ban handguns, most importantly the publication of the report of the Cullen inquiry and the formation of the Snowdrop Campaign, which managed to exert massive pressure on political decision-makers (Karp 2003). However it can be questioned whether both would have had a comparable impact if the Conservative party had cohesively opposed gun policy change in the immediate aftermath of the tragedy or if the status quo advocates would have been more successful in deflecting the public debate towards other policy issues. In addition, it is unlikely that a sweeping policy change would have been possible had the Labour side suffered any defections.

In sum, the Dunblane case supports $\mathrm{H} 1$ because the status quo coalition suffered at least two very important defections, the discourse was strongly focused on the gun issue and the event eventually led to a major policy change in Great Britain's gun policies.

\section{Erfurt - discursive foundations of incremental policy change}

The Erfurt affiliation network (Figure 4), displays a much more complex structure than the Dunblane network regarding the number of frames and actors. Although the majority of statements were made with regard to guns, a range of other relevant discourses developed, ranging from a debate over violent video games to specific arrangements in Germany's education system and general concern over developments in Germany's civil society. This resulted in a much more diffuse debate than the one at Dunblane and led to the discourse participation of a multitude of individual actors.

There was broad agreement that strengthening security arrangements in schools would not be an appropriate response to the shooting. A typical concern in this context was that schools could become 'fortresses', a metaphor we also encountered in the discourses following Dunblane and Zug. Likewise, the majority of discourse participants agreed that changes should be made in the education system and that access to violent media content should be restricted. With regard to the gun discourse, there is clear evidence of a highly cohesive change coalition consisting of members of the Social Democratic Party (SPD) and the Green Alliance. We observe opposition primarily 


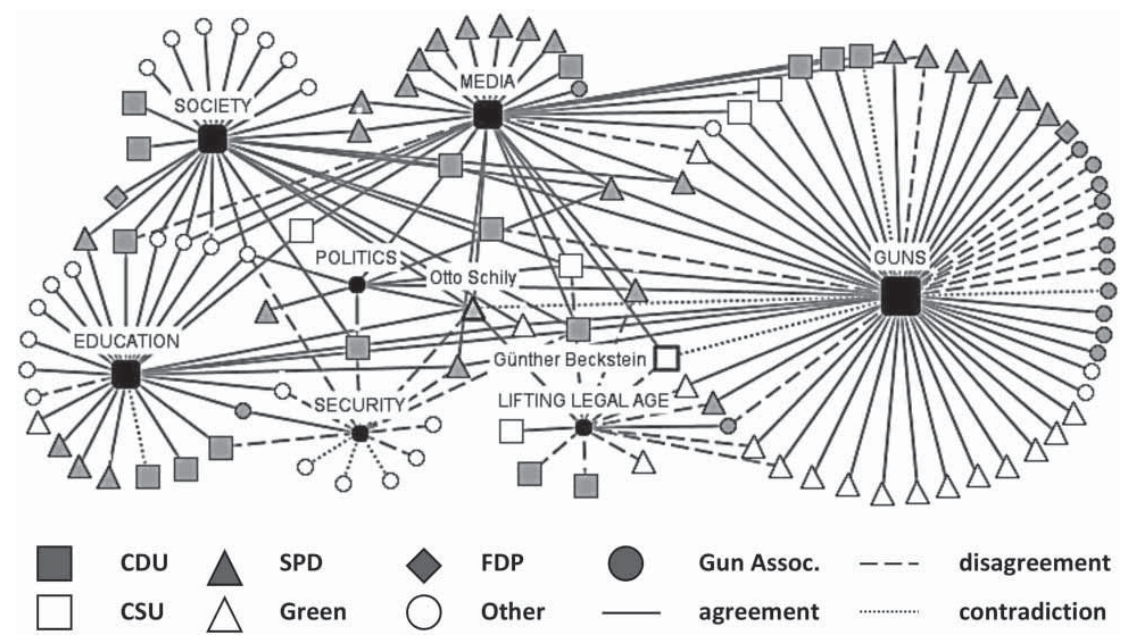

Figure 4 Erfurt discourse network

from the gun lobby or individual shooting clubs, but there is also evidence that even those actors were willing to concede to some gun policy changes, albeit to a much lesser extent than the Christian Democratic and Christian Social Union (CDU/CSU). After initial efforts to frame the Erfurt shooting as a societal failure and the result of the corrupting influence of violent video games, the opposition moved towards accepting the need to change certain gun policies, including (among others) a lifting of age requirements and a prohibition of pump guns. The major individual actors in the discourse were the Minister of the Interior Otto Schily (SPD) and Günther Beckstein (CSU), who was deemed to become Schily's successor in an eventual election victory in September of 2002. Both were initially sceptical about the need to tighten gun regulations, but changed their opinions as new information on the shooting's circumstances became available and their coalition colleagues started to endorse change.

The opposition thereby succumbed to mounting pressure to take a stance on guns and found it hard to deflect the debate on one single alternative issue. The special circumstance that the German Bundestag had just voted in favour of a tighter weapon law on the morning the shooting took place certainly accelerated the political process. It only took a few days until general agreement emerged over the need to further tighten some of the newly changed regulations, which was accomplished in the conciliation committee of the German Bundesrat.

Thus, the Erfurt case supports our $\mathrm{H} 2$ expectation as the status quo coalition was not particularly cohesive, the discourse following the incident was highly dispersed and, accordingly, the subsequent changes in Germany's gun policies were incremental in nature. 


\section{Zug - discursive foundations of deadlock}

The Zug discourse (Figure 5), illustrates the strong focus on security matters in the wake of the massacre, compared with the lower relevance of the gun issue. The need for changes in security measures was quite contested among the various participants. Many saw the Swiss tradition of a transparent relationship between political representatives and the public endangered by overly restrictive new security arrangements and therefore withheld support. Yet, as the graph in Figure 5 shows, several actors from different backgrounds also endorsed calls for tighter security measures and the lines between the camps are blurry.

With regard to guns, the network shows strong cohesion within the Socialdemocratic Party (SP) on the need for tighter rules in the Swiss firearm regime, which is one of the most liberal ones in Europe. The graph suggests that the Christian Democratic People's Party (CVP) belongs to the same coalition as the SP. However, all of the CVP statements we counted as agreeing to gun policy changes were extremely diffuse and unspecific when compared to the very focused consequences demanded by the SP. ${ }^{5}$ Such unspecific statements like assurances to 'review' the current laws imply ostensible concessions and are likely to be made primarily in an attempt to win time. Therefore, we conclude that both change and status quo advocates exhibited high cohesion in their support and their rejection of gun policy changes. As a result, and in addition to the already low magnitude of the gun discourse, it hardly comes as a surprise that deadlock occurred and no gun policy changes were implemented in Switzerland in the wake of the Zug massacre. Yet, security measures in public buildings were bolstered in many parts of the country as a response to the

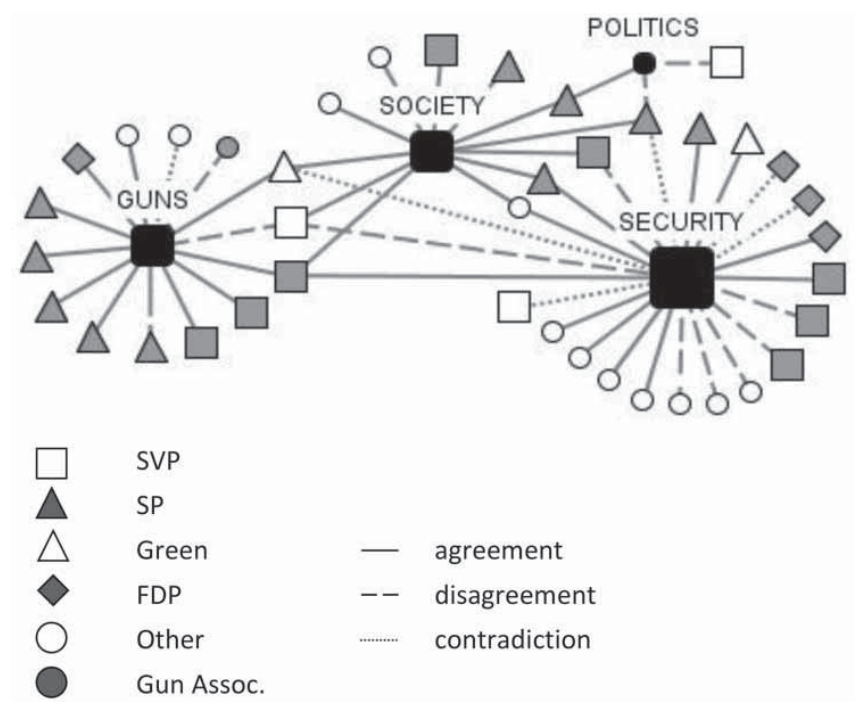

Figure 5 Zug discourse network 
shooting (Raaflaub 2011), which lends some support to our general argument on the relevance of discursive complexity. In sum, the empirical evidence suggests that the Zug case supports $\mathrm{H} 3$.

\section{CONCLUSION}

Drawing on theoretical frameworks that emphasize the relevance of focusing events as catalysts for policy change (Birkland 2006; Boin et al. 2009; Kingdon 2003), this contribution tested the extent to which the varying occurrence and degree of gun-related policy change after shooting rampages can be traced back to the cohesion of the status quo coalition on the issue of gun control and the general variance of interpretative frames brought forward by different actors in the immediate aftermath of the events. We based our empirical analysis upon statements made by different actors in the news media following the first month after the shooting rampages at Erfurt (Germany), Dunblane (United Kingdom) and Zug (Switzerland), which all led to different levels of change in the three countries' gun policies.

The extent to which the discourses were dispersed among different issues varied strongly. In Dunblane, guns were the dominant issue, which made it hard for advocates of the status quo to deflect popular attention to other policy issues or dilute the debate by pointing to threats of general societal norms. At the same time, several prominent Conservatives either voiced their willingness for concessions early on (as in the case of Prime Minister Major) or even played a central role in the change movement (as in the case of MP David Mellor). Also in Erfurt, gun control was the major issue, but much more than in Dunblane the discourse also extended to several other policy areas. However, the gun status quo advocates not only failed to make those competing issues dominant, they also failed to keep their cohesion with regard to the gun issue. This resulted in a range of incremental changes, but it did not result in a large-scale change like in Dunblane. This difference was certainly also owing to the lack of a dedicated pro-change social movement in Erfurt and the later emergence of such a group, the Snowdrop Campaign, in Dunblane (Karp 2003). Finally, in contrast to the shootings in Dunblane and Erfurt, the shooting in Zug resulted in a discourse that primarily focused on matters of security, whereas gun control was a side issue. Within the gun control debate, however, we observed a status quo coalition which collectively watered down the gun debate by making only diffuse and unspecific pledges. As a result, the Zug debate petered out without any concrete changes as the momentum for policy change faded.

On a theoretical level, the contribution has several implications. First, discursive elements are worth exploring as pieces of the larger puzzle of policy change. Shifts in problem perceptions and corresponding volatility of competing discourse coalitions are interesting phenomena that should be incorporated more systematically in event-based explanations of policy change. Such an approach could further improve our understanding of the emergence and 
exploitation of policy windows in the aftermath of focusing events (Boin et al. 2009; Kingdon 2003). This is because statements made in response to external shocks can be interpreted as manifestations of actor preferences and the resulting discourse networks are indicative of the actual size of the policy window. Second, our contribution suggests that a more profound micro-foundation of existing theoretical frameworks is imperative. Locating the analytical focus on the frames advanced by individual actors could inform us more deeply about their motivations and strategies in order to prevent or facilitate policy change. Finally, we claim that the processes we highlighted in this contribution should be particularly relevant if the respective event has the potential to be framed as a threat to basic moral values. The resulting clash of frames and counter-frames after events which are based on human failure can be expected to be of higher intensity than after focusing events that are based on technical deficiencies (e.g., plane crashes) or events of non-human, or at least only indirect human, causation (e.g., natural disasters). The involvement of private human failure or misconduct is particularly prevalent in morality policies and makes related events susceptible to moral exploitation, especially if the conflict of values is usually latent and only erupts as a result of the event (Heichel et al. 2013; Knill 2013).

We have demonstrated that framing and policy change are two sides of the same coin in the aftermath of external shocks like shooting rampages. However, whether or not gun policies change as a result of such events hinges on many additional factors and the processes discussed in this contribution are not sufficient explanations. In addition to imminent elections (Boin et al. 2009), also national gun traditions, competing focusing events and prior policy configurations can also have an impact on whether or not gun policies change. Most importantly, institutional variables on the level of the political systems certainly constrain or facilitate policy change to varying extents in the further political process. However, we would like to point out that the emergence of the political discourse after an external shock precedes this process and is therefore worth exploring in its own right. After all, in order to understand why a problem is dealt with politically and subjected to the decision-making process, we must first understand why it is actually seen as a problem.

Finally, future research endeavours should broaden the empirical focus. For instance, distinguishing between actors in terms of their procedural power could lead to additional insights about which group of actors dominates the discourse. Moreover, we suggest that our hypotheses are transferable to other empirical contexts and would therefore like to encourage scholars to take up our line of inquiry by examining other types of external shocks and areas of public policy. Such a research programme could eventually lead to a more thorough understanding of how different societies process sudden and disruptive events politically.

Biographical notes: Steffen Hurka and Kerstin Nebel are PhD candidates and research assistants at the University of Konstanz, Germany. 
Address for correspondence: Steffen Hurka, Chair of Comparative Public Policy and Administration, University of Konstanz, PO Box D 91, 78457 Konstanz, Germany. email: steffen.hurka@uni-konstanz.de/Kerstin Nebel, Chair of Comparative Public Policy and Administration, University of Konstanz, PO Box D 91, 78457 Konstanz, Germany. email: kerstin.nebel@ uni-konstanz.de

\section{ACKNOWLEDGEMENTS}

We thank our three anonymous referees for their constructive comments. This contribution is based on the project MORAPOL (ERC Advanced Grant). We gratefully acknowledge the generous funding by the European Research Council.

\section{NOTES}

1 Note that this argument is also closely linked to the Advocacy Coalition Framework (Sabatier 1998). However, Sabitier's framework explicitly requires the researcher to look at a decade or more, while our focus lies on rapid policy change after an external shock.

2 These networks can be visualized by other software packages such as visone or UCINET.

3 Germany: Frankfurter Allgemeine Zeitung and Süddeutsche Zeitung, United Kingdom: The Guardian and The Independent, Switzerland: Neue Zürcher Zeitung and Der Tagesanzeiger.

4 Dunblane: 171 articles, 106 statements; Erfurt: 408 articles, 311 statements; Zug: 76 articles, 84 statements. A list of the analysed articles can be made available upon request.

5 We decided not to differentiate between diffuse and focused statements in our net works, because this would have made them more confusing and harder to interpret. In Erfurt and Dunblane, we observed that diffuse statements generally spread across different types of actors, but not so much in Zug.

\section{REFERENCES}

Albright, E.A. (2011) 'Policy change and learning in response to extreme flood events in Hungary: an advocacy coalition approach', Policy Studies Journal 39(3): 485511.

Baumgartner, F.R. and Jones, B.D. (1993) Agendas and Instability in American Politics, Chicago, IL: The University of Chicago Press.

Birkland, T.A. (2006) Lessons of Disaster: Policy Change after Catastrophic Events, Washington, DC: Georgetown University Press.

Birkland, T.A. and Lawrence, R.G. (2009) 'Media framing and policy change after Columbine', American Behavioral Scientist 52(10): 140525.

Boin, A., t'Hart, P. and McConnell, A. (2009) 'Crisis exploitation: political and policy impacts of framing contests', Journal of European Public Policy 16(1): 81106.

Brown, C. (1996) 'Government orders review of gun laws', The Independent, 20 March 1996.

Chapman, S., Alpers, P., Agho, K. and Jones, M. (2006) 'Australia's 1996 gun law reforms: faster falls in firearm deaths, firearm suicides, and a decade without mass shootings', Injury Prevention 12(6): 36572. 
Cohen, S. (2002) Folk Devils and Moral Panics, 3rd edn, London: Routledge.

De Vries, M.S. (2004) 'Framing crises: response patterns to explosions in firework factories', Administration \& Society 36(5): 594614.

Euchner, E M., Heichel, S., Nebel, K. and Raschzok, A. (2013) 'From "morality" policy to "normal" policy: framing of drug consumption and gambling in Germany and the Netherlands and their regulatory consequences', Journal of European Public Policy 20(3), doi: 10.1080/13501763.2013.761506

Haider Markel, D.P. and Joslyn, M.R. (2001) 'Gun policy, opinion, tragedy, and blame attribution: the conditional influence of issue frames', The Journal of Politics 63(2): 52043.

Heichel, S., Knill, C. and Schmitt, S. (2013) 'Public policy meets morality: conceptual and theoretical challenges in the analysis of morality policy change', Journal of European Public Policy 20(3), doi: 10.1080/13501763.2013.761497

Hewitt, K. (1983) 'The idea of calamity in a technocratic age', in K. Hewitt (ed.), Interpretations of Calamity, London: Allen and Unwin, pp. 332.

Jemphrey, A. and Berrington, E. (2000) 'Surviving the media: Hillsborough, Dunblane, and the press', Journalism Studies 1(3): 46983.

Karp, A. (2003) 'Dunblane and the international politics of gun control', in S. Nagel (ed.), Policymaking and Peace A Multinational Anthology, Boston, MA: Lexington Books, pp. 193211.

Kingdon, J.W. (2003) 'Agendas, Alternatives and Public Policies', 2nd edn, New York: Longman.

Knill, C. (2013) 'The study of morality policy: analytical implications from a public policy perspective', Journal of European Public Policy 20(3), doi: 10.1080/ 13501763.2013 .761494

Leifeld, P. (2012) 'Discourse networks and German pension politics', Ph.D. thesis, University of Konstanz.

Lodge, M. (2011) 'Risk, regulation and crisis: comparing national responses in food safety regulation', Journal of Public Policy 31(1): 2550.

Lodge, M. and Hood, C. (2002) 'Pavlovian policy responses to media feeding frenzies? Dangerous dogs regulation in comparative perspective', Journal of Contingencies and Crisis Management 10(1): 113.

Nohrstedt, D. (2008) 'The politics of crisis policymaking: Chernobyl and Swedish nuclear energy policy', Policy Studies Journal 36(2): 25778.

Raaflaub, C. (2011) 'Balancing security with freedom', available at http://www. swissinfo.ch/eng/politics/internal affairs/Balancing security with freedom .html? cid $=31183432$ (accessed 12 July 2012)

Rochefort, D.A. and Cobb, R.W. (1993) 'Problem definition, agenda access, and policy choice', Policy Studies Journal 21(1): 5671.

Sabatier, P.A. (1998) 'The advocacy coalition framework: revisions and relevance for Europe', Journal of European Public Policy 5(1): 98130.

Schmitt, S., Euchner, E. M. and Preidel, C. (2013) 'Regulating prostitution and same sex marriage in Italy and Spain: the interplay of political and societal veto players in two Catholic societies', Journal of European Public Policy 20(3), doi: 10.1080/ 13501763.2013 .761512

Stone, D. (1989) 'Causal stories and the formation of policy agendas', Political Science Quarterly 104(2): 281300. 